\title{
Evaluation of Independent Innovation Capability of Enterprises Based on Factor Analysis
}

\author{
Xin Zhu \\ Department of Management, \\ Guangxi University of Science and Technology, \\ Liuzhou, P.R.China \\ 5266736@qq.com
}

\author{
Liang Xu \\ Department of Management, \\ Guangxi University of Science and Technology, \\ Liuzhou, P.R.China \\ 391550209@qq.com
}

\begin{abstract}
Innovation is an inexhaustible motive force for the advancement and development of enterprise. This paper sets up an appraisal system for independent innovation capability of enterprises, including three indicators: innovation activities, innovation inputs and innovation outputs, and with the help of factor analysis, it gives an empirical analysis of relative enterprise data in China. Then a comparison between Guangxi province and other provinces reveals problems and things to the improved in independent innovation capability of Guangxi enterprises. Lastly, we make a discussion and put forward corresponding suggestions for the improvement of Independent Innovation Capability for Guangxi.
\end{abstract}

Keywords- factor analysis; independent innovation; improvement measures; evaluation system

\section{INTRODUCTION}

Report of the 18th CPC National Congress proposed that relying on the technological power is the most fundamental and improving autonomous innovative capacity substantially is the most crux and promoting our country's economic and social development to be on the track driven by innovation as soon as possible in order to achieve scientific development and accelerate the transformation of economic development. National Science and Technology Conference held in 2012 enacted the principles of science and technology development that making independent innovation, leapfrogging advances in key areas, supporting development and leading a better future. Guangxi science and technology innovation conference held in September 30.2012 pointed that we should always implement the scientific development concept thoroughly and the strategies vigorously of rejuvenating the Guangxi through human resource and development with science and technology in the outstanding position and focus on innovating scientific and technological institutional mechanism to make important contributions constantly for Guangxi stable and rapid economic and social development with the improvement of independent innovative capability as a core and implementation of independent innovative projects in Guangxi as the starting point.

The improvement of the independent innovation capability and building an innovation-oriented country are the core driving force and also the key to enhance the comprehensive national strength [1]. And enterprises are the main body of autonomous innovation and the crux to enhance national capacity for autonomous innovation. In the process of economic globalization, facing increasingly fierce competition and increasing pressure, enterprises must master the relevant technique and property right and fully improve their own innovation capability at the same time in order to obtain deeper development in the future. Nationwide, economic and technological development level in Guangxi is lagging behind and industrialization level is not high [2]. Meanwhile, the capability of independent innovation in Guangxi is poor and industrial technology depended mostly on external input. Accelerating the pace of autonomous innovation must be paid attention to in order to achieve the improvement of corporate core competitiveness, thereby promote overall economic development in Guangxi. Therefore, how to improve capability of corporate independent innovation in Guangxi becomes a pressing issue [3]. This paper evaluated the capability of corporate independent innovation in Guangxi through factor analysis and concluded several factors with the greater impact on the capability of corporate independent innovation. Then, this paper analyzed the results and put forward proposed reference in order to improve the capability of corporate independent innovation in Guangxi.

\section{CONSTRUCTION OF EVALUATION INDEX FOR INDEPENDENT INNOVATION CAPABILITY}

Through the research of pre-existing literature, we can find that many domestic and foreign scholars have different standpoints concerning the evaluation indicator system of capability of corporate independent innovation based on the different viewing angles and position of analyzing problems, and the unified evaluation indicator system has not yet been formed [4]. Although the scholars did not select the same indicators, from the comprehensive standpoint, innovative input capability, innovative activities capability and innovative production capability are the core contents and similar points of evaluation system of capability of corporate independent innovation. For example, the factor of manufacturing capability can be incorporated into the corporate innovation input; the capability of $\mathrm{R} \& \mathrm{D}$, the capability of digestion and absorption and the capability of internal management can be incorporated into innovative activities capability; and the capability of marketing and sales revenue from new products can be incorporated into innovation output capability. In order to ensure effective and comprehensive economic indicator system and make analysis process easier to be quantitative ,this 
paper mainly integrated indicator system constructed by academic predecessors and eliminated the indicators that are close correlative, weak representative, and covering the small amount of information to construct the evaluation system of corporate independent innovation capability from three aspects as the capability of innovation output, innovation activities and innovation output. And there are 13 secondary indicators in the first grade indicators. The result is shown in table I .

TABLE I. EVALUATION IDEX OF INDEPENDENT INNOVATION CAPABILITY

\begin{tabular}{|c|c|c|}
\hline first level index & second level index & Variable \\
\hline \multirow{4}{*}{$\begin{array}{l}\text { Capability of } \\
\text { innovation input }\end{array}$} & $\begin{array}{l}\text { Technological activity staff } \\
\text { accounted for the proportion of } \\
\text { employees }\end{array}$ & $X_{1}$ \\
\hline & Intensity of R \& D expenditure & $X_{2}$ \\
\hline & $\begin{array}{l}\text { Intensity of investment in scientific } \\
\text { and technological activities }\end{array}$ & $X_{3}$ \\
\hline & $\begin{array}{l}\mathrm{R} \& \mathrm{D} \text { personnel accounted for the } \\
\text { proportion of employees }\end{array}$ & $X_{4}$ \\
\hline \multirow{5}{*}{$\begin{array}{l}\text { Capability of } \\
\text { innovation } \\
\text { activities }\end{array}$} & Digestion and absorption of funds & $X_{5}$ \\
\hline & $\begin{array}{l}\text { Purchase of foreign technology } \\
\text { spending }\end{array}$ & $X_{6}$ \\
\hline & $\begin{array}{l}\text { Purchase of domestic technology } \\
\text { spending }\end{array}$ & $X_{7}$ \\
\hline & $\begin{array}{l}\text { The number of business } \mathrm{R} \& \mathrm{D} \\
\text { projects }\end{array}$ & $X_{8}$ \\
\hline & Funding of business R \& D project & $X_{9}$ \\
\hline \multirow{4}{*}{$\begin{array}{l}\text { Capability of } \\
\text { Innovation } \\
\text { output }\end{array}$} & New product sales & $X_{10}$ \\
\hline & The number of patent applications & $X_{11}$ \\
\hline & $\mathrm{R} \& \mathrm{D}$ projects of new product & $X_{12}$ \\
\hline & The number of invention patents & $X_{13}$ \\
\hline
\end{tabular}

\section{EMPIRICAL STUdy ON THE EVALUATION OF THE INDEPENDENT INNOVATION CAPABILITY}

\section{A. KMO and Bartlett's Test}

Data coming from twenty-eight areas in our country except Tibet and Hainan (statistical data in Tibet and Hainan are not complete) were compared with the statistical data in Guangxi. All data are from the " 2012 Chinese Statistical Yearbook" and "2012 Chinese Statistical Yearbook on science and technology" Firstly, the raw data is processed through the statistical analysis software, and then the correlated coefficient matrix with the original variables is standardized. Most correlated coefficiency is greater than 0.3 , therefore, variables have strong correlation and factor analysis is appropriate. In this inspection, the result of KMO is 0.773 and the result of Bartlett ball is 814.430 , which mean factor analysis is eligible.

\section{B. Determining the Number of Factors}

As is seen from the analysis, the characteristic values of the first three factors were 8.053, 2.682, 1.184, accumulating of
91.682 percent variance of contribution rate. According to the principle that eigenvalue is greater than 1 , the first three factors can be extracted. Cumulative contribution rate is greater than $85 \%$, indicating that these three factors can be summarized with most information of original variables. Therefore, analyzing independent innovation capability of enterprises by first three factor is appropriate.

\section{Extracting Common Factors and Naming}

By analyzing the indicators loaded on the factor, factors are named.The first main factor is mainly loaded in the five aspects:(intensity of investment in scientific and technological personnel), (intensity of $\mathrm{R} \& \mathrm{D}$ expenditure), (intensity of investment in scientific and technological activities), ( $R \& D$ personnel accounted for the proportion of employees), (funding of business R \& D project). These indicators reflect the input of independent innovation capability, which can be named as input capacity factor. The rate of variance contribution of first main factor reaches $39.168 \%$, indicating that input capacity is the most important factor affecting the ability of independent innovation.

The second factor is mainly loaded in five aspects:(new product sales), (the number of patent applications), (R \& D projects of new products), (the number of invention patents), (the number of business $\mathrm{R} \& \mathrm{D}$ projects). These indicators reflect output capacity of independent innovation, which can be named as innovation output capacity factor. The second contribution rate of main factor variance reaches $32.806 \%$, indicating that output capacity is the second important factor affecting the ability of independent innovation.

The third main factor is mainly loaded in three aspects:(digestion and absorption of funds), (purchase of foreign technology spending), (purchase of domestic technology spending). These indicators reflect extent of digestion and absorption of foreign technology introduction and thus reflect the secondary innovation capacity of business. Therefore, this factor can be named as introduction into absorption capacity factor.

\section{Calculation of Each Factor Score and Comprehensive Factor Score}

In order to sort the factor scores, the factor score matrix is obtained with linear regression method. The result is shown in Table II. Weighing three main factors scores and calculating the rate called main factor accounted for the proportion of the cumulative variance contribution. Integrated factor score function has been got.

$$
\mathrm{F}=0.39168 \mathrm{~F}_{1}+0.32806 \mathrm{~F}_{2}+0.19709 \mathrm{~F}_{3}
$$

Comprehensive score can be calculated according to the function of the factor scores and the total score. Overall score of each factor and composite score, each factor score, and rank of total score are shown in Table III. 
TABLE II. COMPONENT SCORE COEFFICIENT MATRIX

\begin{tabular}{|l|c|c|c|}
\hline & \multicolumn{3}{|c|}{ component } \\
\hline & 1 & 2 & 3 \\
\hline $\begin{array}{l}\text { intensity of investment in } \\
\text { scientific and technological } \\
\text { personnel }\end{array}$ & -0.055 & 0.242 & -0.003 \\
\hline intensity of R \& D expenditure & -0.074 & 0.253 & 0.018 \\
\hline $\begin{array}{l}\text { intensity of investment in } \\
\text { scientific and technological } \\
\text { activities }\end{array}$ & -0.089 & 0.288 & -0.072 \\
\hline $\begin{array}{l}\text { R \& D personnel accounted for } \\
\text { the proportion of employees }\end{array}$ & -0.055 & 0.242 & -0.002 \\
\hline digestion and absorption of funds & -0.196 & -0.004 & 0.530 \\
\hline $\begin{array}{l}\text { purchase of foreign technology } \\
\text { spending }\end{array}$ & 0.014 & -0.017 & 0.250 \\
\hline $\begin{array}{l}\text { purchase of domestic technology } \\
\text { spending }\end{array}$ & -0.138 & -0.065 & 0.500 \\
\hline $\begin{array}{l}\text { the number of business R \& D } \\
\text { projects }\end{array}$ & 0.114 & 0.120 & -0.076 \\
\hline $\begin{array}{l}\text { funding of business R \& D } \\
\text { project }\end{array}$ & 0.164 & 0.027 & -0.033 \\
\hline new product sales & 0.202 & -0.059 & -0.005 \\
\hline number of patent applications & 0.263 & -0.074 & -0.104 \\
\hline R \& D projects of new product & 0.214 & -0.045 & -0.047 \\
\hline number of invention patents & 0.317 & -0.079 & -0.223 \\
\hline
\end{tabular}

\section{ANALYSIS OF EVALUATION RESULTS}

Seen from the comprehensive scores of main factors, the capacity of coporate autonomous innovation in Guangxi ranked 24th, which is in the extremely level backward on a national wide scale far behind some developed regions. Seen from the ranking of three main factors, its autonomous innovation inputs rank 15th which is in the mid-level in the whole country, and outputs rank 22nd and transformation and absorption rank 20th. The latter two main factors are both the lower ranked locations on a national wide scale. And since the inputs of autonomous innovative capacity have the greatest influence on autonomous innovation,the cause of backward of autonomous innovative capacity of enterprises in Guangxi are a small amount of innovation outputs and neglection of introduction and absorption of external technology.

\section{A. Analysis of Innovative Input Indicator}

Enterprises in Guangxi, compared with the developed cities and provinces, have a moderate investment level of independent innovation, which is mainly manifested in human resources and economic resources [5]. From the perspective of several secondary indexes, personnel and capital investment strength in scientific and technological activities rank comparatively high in the country, while the proportion of $R \& D$ personnel investment in personnel and $R \& D$ capital investment is low.

TABLE III. COMPARISON OF FACTOR SCORES OF PROVINCES

\begin{tabular}{|c|c|c|c|c|c|c|c|c|}
\hline & \multicolumn{2}{|c|}{ Innovation input factor } & \multicolumn{2}{|c|}{ Innovation output factor } & \multicolumn{2}{|c|}{$\begin{array}{l}\text { Introduction into absorption } \\
\text { capacity factor }\end{array}$} & \multicolumn{2}{|c|}{ Composite score } \\
\hline & F1 & Sequence & F2 & Sequence & F3 & Sequence & Composite & Sequence \\
\hline Jiangsu & 2.19958 & 2 & -0.01494 & 10 & 2.06966 & 3 & 1.26454 & 1 \\
\hline Guangdong & 3.77711 & 1 & -0.30985 & 16 & -0.91086 & 29 & 1.198248 & 2 \\
\hline Beijing & -0.42635 & 21 & 4.33928 & 1 & -0.67274 & 23 & 1.123961 & 3 \\
\hline Shanghai & -0.24096 & 13 & 1.02709 & 3 & 2.725 & 1 & 0.779638 & 4 \\
\hline Zhejiang & 1.74248 & 3 & 0.27273 & 7 & -0.16224 & 12 & 0.73999 & 5 \\
\hline Shandong & 0.81736 & 4 & -0.01544 & 11 & 1.44278 & 4 & 0.599436 & 6 \\
\hline Tianjin & -0.33558 & 19 & 1.31766 & 2 & 0.10443 & 9 & 0.321414 & 7 \\
\hline Hubei & 0.00486 & 7 & 0.62956 & 4 & -0.66039 & 21 & 0.078281 & 8 \\
\hline Anhui & -0.01384 & 8 & 0.15862 & 8 & -0.06081 & 10 & 0.034631 & 9 \\
\hline Hunan & 0.07967 & 6 & -0.03472 & 12 & -0.40881 & 17 & -0.06076 & 10 \\
\hline Fujian & -0.11719 & 10 & -0.26084 & 15 & 0.27473 & 8 & -0.07733 & 11 \\
\hline Shanxi & -0.55428 & 27 & 0.52438 & 6 & -0.20745 & 13 & -0.08596 & 12 \\
\hline Liaoning & -0.22875 & 12 & -0.3113 & 17 & 0.49867 & 5 & -0.09344 & 13 \\
\hline Chongqing & -0.27017 & 14 & 0.05177 & 9 & -0.30725 & 15 & -0.14939 & 14 \\
\hline Heilongjiang & -0.50385 & 25 & 0.5601 & 5 & -0.73584 & 26 & -0.15863 & 15 \\
\hline Sichuan & 0.11296 & 5 & -0.1989 & 13 & -0.70807 & 25 & -0.16056 & 16 \\
\hline Henan & -0.02584 & 9 & -0.39906 & 18 & -0.16054 & 11 & -0.17268 & 17 \\
\hline Hebei & -0.3112 & 17 & -0.58703 & 23 & 0.29243 & 7 & -0.25684 & 18 \\
\hline Neimenggu & -1.35062 & 29 & -0.92347 & 29 & 2.65596 & 2 & -0.3085 & 19 \\
\hline Gansu & -0.84618 & 28 & -0.26006 & 14 & 0.33132 & 6 & -0.35145 & 20 \\
\hline Shanxi & -0.47885 & 22 & -0.46407 & 19 & -0.25595 & 14 & -0.39024 & 21 \\
\hline Jilin & -0.20597 & 11 & -0.59762 & 24 & -0.67206 & 22 & -0.40919 & 22 \\
\hline Guangxi & -0.28554 & 15 & -0.58547 & 22 & -0.62735 & 20 & -0.42755 & 23 \\
\hline Yunnan & -0.48979 & 24 & -0.50282 & 21 & -0.37096 & 16 & -0.42991 & 24 \\
\hline Jiangxi & -0.28886 & 16 & -0.64502 & 25 & -0.59973 & 19 & -0.44295 & 25 \\
\hline Ningxia & -0.55321 & 26 & -0.49897 & 20 & -0.58198 & 18 & -0.49508 & 26 \\
\hline Guizhou & -0.32752 & 18 & -0.73999 & 27 & -0.77306 & 27 & -0.52341 & 27 \\
\hline Xinjiang & -0.39114 & 20 & -0.84386 & 28 & -0.70752 & 24 & -0.56948 & 28 \\
\hline Qinghai & -0.48834 & 23 & -0.68775 & 26 & -0.81135 & 28 & -0.57681 & 29 \\
\hline
\end{tabular}


The low percentage of $R \& D$ personnel results from the backward technical infrastructure and the lack of scientific research funds failing to attract and retain scientific and technological talents [6]. There are only 58 regular higher educational institutions in Guangxi, not to mention 985 and 211 project university and other scientific research institutions. These limitations lead to the poor scientific and academic atmosphere of Guangxi, and talents of high quality and strong capability are not willing to stay in Guangxi and most of key university graduates choose not go back to work in Guangxi. The R\&D capital investment level of Guangxi enterprises, lagging behind the national level, is $0.69 \%$, which means the serious shortage of R\&D capital investment in Guangxi. The low R\&D investment level shows that enterprises mainly focus on the low-level technology instead of the high-level scientific research. There is a recognized survival line for enterprises: the R\&D investment level should be at least $2 \%$. According to this standard, most enterprises in Guangxi are in difficulties, which will affect the independent innovation of enterprises.

\section{B. Analysis of Innovative Output Indicator}

From several secondary indicators evaluation, the sales revenue and research and development project of new products ranked lower in the national level, which suggests the enterprises' technological outputs are relatively low so as to further strengthen the research and development capacity in Guangxi. New products are the most important and direct reflection of corporate scientific and technological innovation achievements [7]. Any one of these companies most constantly does new product research and development in order to achieve enterprises' value of autonomous innovation, and bring new way of profit growth, and meet the variable market demands to gain competition advantage. The number of applications for patents and ownership of invention was one of the lowest ranking locations similarly on the national scale which reflects the phenomenon that scientific and technical personnel's innovation outputs in Guangxi are far less than that in the developed regions, and the quality is poor, and the core technology is not highlighted, lacking of the innovative product that are of national influence [8]. That the level of scientific and technical research and development is low can also reflect the poor awareness of corporate patents and intellectual property rights protection, therefore it is difficult to form core technology and brand with own intellectual property rights. There are more than 40 national and provincial key laboratories and several large and medium-scale scientific research institutes [9]. However, one of the reasons why the innovative outputs in Guangxi are very small lies in that enterprises in Guangxi do not build cooperative relationship with colleges and related scientific research institute. In other words, those enterprises in Guangxi do not fully utilize the resources and strength of colleges and scientific research institute limits the transformation and improvement of productivity.

\section{Analysis of Introduction into Absorption Capacity Factor}

The introduction and digestion of technology play an important role and have influence on enterprise autonomous innovation. For enterprises in Guangxi compared with developed regions ,funds and technology are relatively backward, which suggests enterprises in Guangxi do not attach importance to the introduction of domestic and international advanced technology and the duplication and absorption [10]. Meanwhile, introduction of duplication is serious, causing resources to be seriously wasted in turn, leading that secondary innovative capability is relatively weak, taking corporate autonomous innovation as example, if it is only by imitation and copy rather than technological transformation and innovation combined with their own characteristics, which will result in the low production technology content, low addedvalue and weak enterprise competitiveness in the market, and it will eventually fall behind other businesses ,forever relying on foreign technology.

\section{ACKNOWLEDGMENT}

This research is supported by the Foundation of Guangxi Software Committee (Grant No: 12252034)

\section{REFERENCES}

[1] Zhen Chun Dong, "Assessment study of innovation capacity of enterprises technology", China Soft Science,2009,10,pp.108-110

[2] Peng Ben Hong , Luo Ming Wu,"Assessment of the indicators and methods research of independent innovation capacity of Manufacturing Enterprise ”,Modern Management Science,2008,3,pp.52-53

[3] Cao Chong Yan, Wang Huai Xue, "Study of assessment index of Innovation Capacity of enterprises technology”,Forecast,2007,2,pp.6668

[4] Dong Feng, "The evaluation of the enterprises 'technology innovation ability based on factor analysis", China Soft Science, 2008,22,pp.98102

[5] Jiang Yang, Lu Zhi Yu, "The analysis and evaluation of independent innovation capability of large and medium-sized enterprises in Sichuan province”, China Soft Science, 2011,2,pp.89-93

[6] Xia Zhi Yong, "Empirical evaluation and analysis of the independent innovation capability of large- scale enterprise in China", Studies In Science Of Science, 2008, 26(3),pp.25-27

[7] Xu Ling, Wu Feng Chai, “Assessment of China's high-tech industry and technology innovation capacity", Science \& Technology Progress And Policy, 2011,2,pp.128-132

[8] Zhi Jun, Wang Zhong Hui, "Measured theory of independent innovation capability and building of evaluation indicators ", Management World, 2007,5, pp.168 - 169

[9] Chen Rui, "The appraisal on independent innovation capability of stateowned enterprises_an example of Sichuan province", China Soft Science, 2009,3,pp.64-65

[10] Zhang Hong Cai, “Analysis of the technological innovation capacity of Beijing manufacturing industry",China Science And Technology Forum,2008,7,pp.41-44 